\title{
Neural Stem Cells to Cerebral Cortex: Emerging Mechanisms Regulating Progenitor Behavior and Productivity
}

\author{
№elle D. Dwyer, ${ }^{1}$ Bin Chen, ${ }^{2}$ @Shen-Ju Chou, ${ }^{3}$ @Simon Hippenmeyer, ${ }^{4} \oplus^{-}$Laurent Nguyen, ${ }^{5}$ and \\ 가. Troy Ghashghaei ${ }^{6}$ \\ ${ }^{1}$ Department of Cell Biology, University of Virginia School of Medicine, Charlottesville, Virginia 22908, ${ }^{2}$ Department of Molecular, Cell, and Developmental \\ Biology, University of California, Santa Cruz, California 95064, ${ }^{3}$ Institute of Cellular and Organismic Biology, Academia Sinica, Nankang, Taipei 115, \\ Taiwan, ${ }^{4}$ Developmental Neurobiology, Institute of Science and Technology Austria, Klosterneuburg 3400, Austria, ${ }^{5}$ GIGA-Neurosciences, University of

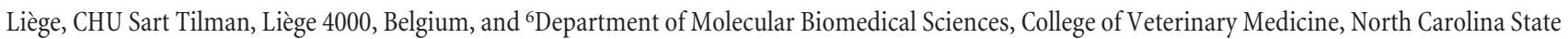 \\ University, Raleigh, North Carolina 27607
}

This review accompanies a 2016 SFN mini-symposium presenting examples of current studies that address a central question: How do neural stem cells (NSCs) divide in different ways to produce heterogeneous daughter types at the right time and in proper numbers to build a cerebral cortex with the appropriate size and structure? We will focus on four aspects of corticogenesis: cytokinesis events that follow apical mitoses of NSCs; coordinating abscission with delamination from the apical membrane; timing of neurogenesis and its indirect regulation through emergence of intermediate progenitors; and capacity of single NSCs to generate the correct number and laminar fate of cortical neurons. Defects in these mechanisms can cause microcephaly and other brain malformations, and understanding them is critical to designing diagnostic tools and preventive and corrective therapies.

Key words: cortical development; Cux2; cytokinesis; Fezf2; Kif20b; Lhx2; lineage; MADM; microcephaly; mouse; neurogenesis; Sp2; UPR

\section{Introduction}

The cerebral cortex is essential for the complex sensory and behavioral capacity of the human species. The neocortex, the sixlayered portion of the dorsal telencephalon, is the most recently evolved part of the cortex in mammals. How this structure with billions of neurons builds itself from a spherical sheet of neuroepithelium is one of the most fascinating mysteries in neuroscience. Much of what we know about this astounding process comes from experiments in rodents, and this review focuses on studies in mice with references to other species where relevant.

Corticogenesis in mice begins between embryonic days 9 and 10 , following specification of the telencephalon at the rostral pole of the neural tube (Fig. 1). The early cortical neural stem cells (NSCs), also called apical progenitors (APs) reside in a polarized epithelium with its apical surface forming the lumen of the tube (future ventricles). APs transition through the cell cycle while their nuclei migrate up and down within the ventricular zone (VZ) of the cortex, a process

\footnotetext{
Received July 25, 2016; revised Aug. 23, 2016; accepted Aug. 30, 2016.

This work was supported by National Institutes of Health Grants R01NS089795 and R01NS098370 to H.T.G., R01NS076640 to N.D.D., and R01MH094589 and R01NS089777 to B.C., Academia Sinica AS-104-TPB09-2 to S.-J.C, European Union FP7-CIG618444 and Human Frontiers Science Program RGP0053 to S.H., and Fonds Léon Fredericq, from the Fondation Médicale Reine Elisabeth, and from the Fonation Simone et Pierre Clerdent to L.N. The authors apologize to colleagues whose work could not be cited due to space limitations.

The authors declare no competing financial interests.

Correspondence should be addressed to either of the following: Dr. H. Troy Ghashghaei, Department of Neurobiology, Department of Molecular Biomedical Sciences, College of Veterinary Medicine, North Carolina State University, 1060 William Moore Drive, Raleigh, NC 27607, E-mail: tghashg@ncsu.edu; or Dr. Noelle D. Dwyer, Department of Cell Biology, University of Virginia School of Medicine, PO Box 800732, Charlottesville, VA 22908-0732. E-mail: ndwyer@virginia.edu.

DOI:10.1523/JNEUROSCI.2359-16.2016

Copyright $\odot 2016$ the authors $\quad 0270-6474 / 16 / 3611394-08 \$ 15.00 / 0$
}

called interkinetic nuclear migration, resulting in the appearance of a pseudostratified epithelium (Fig. 1, left). The nuclei migrate to the basal end of the cell for DNA replication in S-phase, and then to the apical end for mitosis and cytokinesis where the APs are joined by adhesive cell junctions. These cells initially undergo rounds of symmetric divisions to expand their population concomitant with increasing the surface area of the VZ within the two cerebral hemispheres. Symmetric divisions result in both daughter cells retaining a multipotent AP fate with a highly polarized morphology. The number of successful symmetric divisions determines the initial size of the NSC pool, which is crucial for making a cortex of the proper size.

After their early expansion through symmetric divisions, APs begin to divide asymmetrically at $\sim \mathrm{E} 11$ in mice, such that one daughter cell retains its AP identity, whereas the other becomes a neuron (Fig. 1). This is the start of cortical neurogenesis (Fig. 1, Neurogenesis onset). Concurrently, APs begin to express glial markers but maintain their polarized, radial morphology with apical endfoot in, and the tip of their basal process out; hence their alternative name radial glial cells (RGCs). Cell divisions still occur at the VZ surface; however, the neuronal daughters detach or "delaminate" from the apical membrane to migrate out of the VZ to form the first neuronal layer, the preplate (Miyata et al., 2001; Haubensak et al., 2004). Beginning a few days later, some of the daughters of asymmetric divisions adopt an intermediate progenitor (IP) identity. These delaminate, migrate to the subventricular zone (SVZ), and divide symmetrically once or twice to produce 2-4 neurons (Noctor et al., 2004; Sessa et al., 2008; Tyler et al., 2015). As such, IPs "amplify" the number of neuronal progeny produced per AP division. Mammals also have progen- 


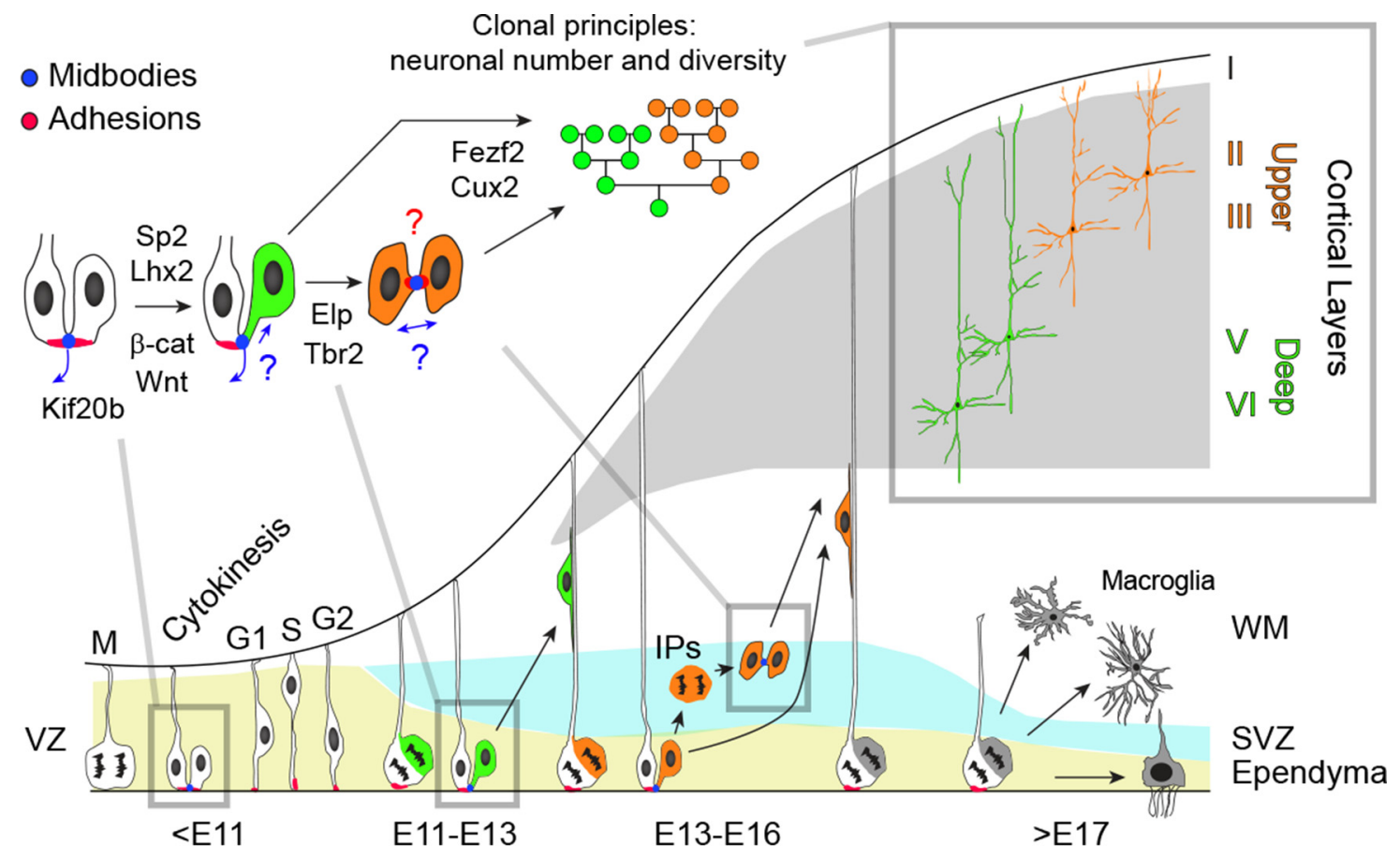

AP expansion Symmetric divisions
Neurogenesis onset Asymmetric divisions

\section{Neurogenesis expansion} IP induction

\section{Gliogenesis}

Figure 1. Spatiotemporal development of the cerebral cortex in mice. This review focuses on the following mechanisms: (1) progenitor cell divisions, including cytokinesis and delamination; (2) induction of neurogenesis and IP generation; and (3) clonal principles that specify the number of neurons and layer fates produced by progenitor divisions. The green and orange neuronal lineages are simplified and do not reflect true numbers of divisions or relative contributions of IPs to deep- versus upper- layer neurons. Blue arrows indicate direction of midbody release or inheritance, with unknown modes indicated by question marks. Distribution of adhesion molecules in IPs is currently unknown (red question mark).

itors in the outer SVZ that have a radial morphology but lack attachments to the apical membrane; these "outer RGCs" may further amplify the AP output and contribute to expansion and gyration of the cortex in larger-brain species (Dehay et al., 2015).

Newborn cortical projection neurons often migrate along the basal processes of APs that are anchored to the basement membrane on the pial surface. Early-born neurons form the deep layers of the cortical plate (layers 5 and 6), and later-born neurons migrate outward past the deep layers to establish the superficial or upper layers (layers 2-4) (Angevine and Sidman, 1961; Rakic, 1972). The temporal sequence of waves of neuronal birth at the ventricle and outward migration to form six successive neuronal layers is referred to as the "inside-out" development of the cortex. These neurons differentiate into glutamatergic pyramidal neurons whose axons form the primary excitatory projections of the cortex. Inhibitory interneurons of the cortex are born in the subcortical ganglionic eminences and migrate in tangentially as the excitatory layers are forming (Anderson et al., 1997; for review, see Chu and Anderson, 2015). Remarkably, as the cortex expands in thickness, the basal processes of APs grow ever taller to span this thickness, always maintaining both their apical and basal contacts. Around the time of birth, cortical neurogenesis dwindles and gliogenesis begins (Gallo and Deneen, 2014).

Cell intrinsic and extrinsic factors are in place for cortical progenitors to produce large numbers of neurons and glia within a short window of development, especially in smaller mammalian species where this process occurs in a matter of a few days. Mechanisms have evolved for precise spatiotemporal control of fate and structure, but at the cost of placing high demand on the cell division machinery (Florio and Huttner, 2014; Homem et al., 2015; Fernández et al., 2016). Indeed, progenitor proliferation and cortical growth are especially vulnerable to environmental or genetic insults. For example, human mutations in mitosis and DNA repair genes can cause microcephaly while sparing most other tissues (Faheem et al., 2015). Cytokinesis, which follows mitosis but is regulated separately, also plays crucial roles in building the cortex, and mutations in cytokinesis genes can also cause malformations, such as microcephaly and microlissencephaly (Harding et al., 2016; Li et al., 2016). While studies of cytokinesis during cortical development have barely begun, tools to study it are rapidly evolving.

Regulation of cytokinesis and control of cortical development The mother cell's organelles and membrane components are partitioned into two daughter cells during cytokinesis. Because the cellular contents are essential for the survival of the daughter cells and perhaps for their final fates, segregation of cellular material must be coordinated with cytokinesis (Jongsma et al., 2015; Knoblach and Rachubinski, 2015). First, the dividing cell is cleaved in two by a contractile furrow, forming an intercellular bridge, which is ultimately severed in a process called abscission. Furrowing is regulated by the central spindle, and abscission appears to be controlled at least in part by the midbody (for review, see Green et al., 2012; Mierzwa and Gerlich, 2014). Most studies of cytokinesis have been performed in single-cell models, such as cell lines or zygotes. Cortical APs face unique challenges for coordinating cytokinesis with interkinetic nuclear migration while maintaining their apicobasal polarity. Moreover, because APs divide either symmetrically or asymmetrically, they must segregate fate determinants accordingly. In addition, abscission at the apical membrane must allow some daughters to delaminate without 
disrupting epithelial integrity. Thus, cytokinesis processes are intimately involved with all the key progenitor behaviors.

The polarized form of cytokinesis that occurs in cortical APs is not well understood. The cleavage furrow ingresses from the basal side toward the apical membrane. The furrow may split the basal process in two (Kosodo et al., 2008), or form next to it, segregating it to one daughter cell (Miyata et al., 2001). Cleavage is often approximately perpendicular to the apical membrane (Noctor et al., 2008). A prevailing hypothesis holds that asymmetric neurogenic divisions result from unequal inheritance of apical membrane or junctions due to unequal cleavage of the apical membrane (Kosodo et al., 2004; Marthiens and ffrenchConstant, 2009). This is analogous to Drosophila neuroblasts, where a 90-degree change in cleavage angle determines whether one or both daughters inherit the apical membrane (Rhyu et al., 1994; Chenn and McConnell, 1995). If this model is correct, then a truly symmetric division requires exquisite coordination of spindle orientation, furrow ingression, and abscission with distribution of apical domain components. The model was revised when cleavage angle failed to always predict daughter fate (Noctor et al., 2008), and mutations that cause irregular cleavage angles affect cortical thickness in some mutants (Postiglione et al., 2011), but not others (Konno et al., 2008). Interestingly, oblique cleavages that segregate the apical endfoot to only one daughter may serve to expand outer RGCs in the primate cortex (LaMonica et al., 2013). Overall, a direct relationship between cleavage orientation and fate determination remains unclear. Moreover, inheritance of additional asymmetric factors aside from the apical membrane, such as the mother centrosome (Wang et al., 2009; Paridaen et al., 2013), the basal process (Tsunekawa et al., 2012), or the midbody (Ettinger et al., 2011; Kuo et al., 2011) have been reported to influence fate specification.

Cytokinetic abscission in cortical progenitors has been studied even less than cleavage furrow ingression. As the furrow ingresses toward the apical membrane, it compacts the microtubules of the central spindle into the midbody, which forms within a cytoplasmic bridge connecting the cleaving cells' apical endfeet. The mammalian midbody contains $>150$ proteins (Skop et al., 2004) and lipids (Arai et al., 2015; Atilla-Gokcumen et al., 2014). Abscission occurs through orderly recruitment of proteins, such as motor proteins, Aurora B kinase, spastin, and the ESCRT III complex; these components promote midbody organization and regulate microtubule breakdown and plasma membrane scission at a constriction point on the flank of the midbody ( $\mathrm{Hu}$ et al., 2012; Mierzwa and Gerlich, 2014). Thus, abscission will occur near the ventricular surface and apical cell junctions, and may arise on one or both sides of the midbody. Accordingly, either one daughter inherits the midbody, or it is released into the extracellular space (Elia et al., 2011; Ettinger et al., 2011). Clearly, the spatiotemporal regulation of abscission is important for determining not only the inheritance of apical components, but also if or when delamination occurs.

As the midbody is the last cytoplasmic link between the mother and daughter cells, it may be a critical final regulator of cell fate or polarity of the daughter. This idea is well supported in yeast, worms, and flies (Salzmann et al., 2014; Singh and Pohl, 2014; Lenhart and DiNardo, 2015; Bernabé-Rubio et al., 2016). In Drosophila sensory progenitors, the point where abscission occurred became the site of first neurite emergence from the daughter neuron (Pollarolo et al., 2011). Apical cilium formation in epithelial cells appears to be influenced by the midbody remnant (Bernabé-Rubio et al., 2016). In mammalian cell lines, midbody inheritance is associated with mother centrosome inheritance
(Kuo et al., 2011), and mother centrosomes may promote cortical progenitor fate (Wang et al., 2009). If the midbody is expelled, it can be engulfed by one of the daughter cells or an unrelated cell (Chai et al., 2012). An inherited midbody remnant may remain stable for some time or be degraded. One group observed that embryonic stem and cancer cell lines accumulated midbody remnants (Kuo et al., 2011). However, another group found that cell lines derived from the nervous system had a tendency to release midbodies and that experimentally increasing midbody retention promoted differentiation (Ettinger et al., 2011). Alternatively, the midbody may bind to cell surface receptors and activate signaling pathways (Crowell et al., 2014). In vivo, early cortical APs appear to release midbodies into the ventricle, and it was hypothesized that this is necessary for both daughters to maintain stemness (Dubreuil et al., 2007). It remains to be confirmed whether midbody inheritance follows stereotyped patterns in different types of cortical progenitor divisions, and whether or not the midbody itself contains fate determinants.

Midbody morphology and abscission are disrupted in the developing cortices of mice mutated in the gene encoding Kinesin- 6 family member Kif20b. These mice show apparent microcephaly by E10. The cortex grows and forms layers in proper order, but all are thinner than normal (Dwyer et al., 2011; Janisch et al., 2013). Interestingly, apoptosis is increased in mutant brains, especially at early stages when symmetric divisions are prevalent. In contrast to several other models of microcephaly, cortical progenitor mitosis does not appear to be disrupted in Kif20b mutants. Cytokinetic furrows and cleavage angles also appear normal. However, midbodies of dividing APs show increased misalignment with the apical membrane, and those that are properly aligned tend to be wider than normal (Janisch et al., 2013; Janisch and Dwyer, 2016). These data suggest that Kif20b is important for midbody structure or maturation, and midbody adhesion to the apical membrane. In the mutant brain, delayed or failed abscissions may cause a subset of apical progenitors to undergo apoptosis, depleting the progenitor pool. Consequently, fewer IPs and neurons are made, and the cortex is small. The precise molecular role of Kif20b in abscission is not yet known. Kif20b protein localizes to the outer flanks of midbodies in dividing apical progenitors (Janisch et al., 2013). Kif20b can slide and bundle microtubules, and knockdown of it in cell lines increases the rate of abscission failure and apoptosis (Abaza et al., 2003). Interestingly, in Kif $20 b$ mutant brains, a subset of thalamocortical axons are misrouted, supporting additional roles for this kinesin in regulating neuron growth (Dwyer et al., 2011; Sapir et al., 2013; Noelle Dwyer, unpublished data).

How abscission and midbody inheritance is coordinated with apical junction inheritance is unclear; however, transcriptional regulators are well poised to coordinate such multipronged mechanisms. Inheritance of apical adhesions is undoubtedly critical to determining which mitotically derived sibling remains anchored to the surface of the VZ and which cell delaminates. As reviewed thus far, delamination involves loss of apical cell-cell junctions, concomitant with gain of capacity to migrate out of the ventricular zone, in contrast to symmetric divisions where both sibling cells maintain their epithelial and stem cell identity (Heng et al., 2010; Asami et al., 2011; Paolini et al., 2015). The extent and nature of these transitions, although postulated, have not been clearly described or mechanistically delineated. Conditional deletion of the transcription factor Specificity Protein 2 (Sp2) disrupts the cell cycle in cortical NSCs and perturbs neurogenesis (Liang et al., 2013), which may be due to defects in the critical balance between symmetric and asymmetric divisions. Recent 
results indicate that $\mathrm{Sp} 2$-dependent transcription drives the induction of asymmetric divisions in cortical NSCs by modulating cytokinesis and delamination (Troy Ghashghaei, unpublished data). Sp2 appears to coordinate these functions through regulation of gene products that can modify the interactions between the midbodies and adhesion machinery of APs.

In summary, regulation of cytokinetic abscission, in addition to mitosis and cleavage, plays an important role in building a cortex of the proper size and structure. The spatial coordination of abscission events and midbody inheritance or release will influence the structure of the neuroepithelium and the size of the progenitor pool, as well as daughter cell fates, delamination, and cell polarity. Defects in cytokinesis may be an unappreciated cause of many developmental brain phenotypes; new methodologies may help uncover these (Janisch and Dwyer, 2016). A better understanding of cytokinetic mechanisms in cortical progenitors will provide insights into the control of cortical size and structure, stem cell renewal, and cortical malformations.

\section{Timing of neurogenesis and its indirect regulation via intermediate progenitors}

The onset of cortical neurogenesis correlates with the appearance of asymmetric divisions in APs. Lhx2, a LIM homeodomain transcription factor, is an important regulator for timing the onset of cortical neurogenesis. Lhx 2 is expressed by APs throughout cortical neurogenesis, and analysis of its expression gradients in the cortical VZ suggested it may repress neurogenesis until the correct time (Suter et al., 2007). Conditional $L h x 2$ deletion in mice ( $L h x 2-c K O)$ leads to a significantly smaller neocortex due to precocious induction of neurogenesis (Chou and O'Leary, 2013; Hsu et al., 2015). Despite this earlier start, sequential generation of each cortical layer remains intact, although they are less dense (especially the upper layers) likely due to depletion of progenitors over time. These results support the model that, once neurogenesis initiates, cortical progenitors follow an intrinsic clock to sequentially generate the different neuronal layers (Shen et al., 2006; Gaspard et al., 2008).

How does Lhx2 prevent premature neurogenesis? The most compelling clue has come from identification of $\mathrm{Lhx} 2$ as a regulator of $\beta$-catenin activity (Hsu et al., 2015). Consequently, disruptions of genes encoding key components of $\beta$-catenin signaling, such as Wnt or Notch, lead to defects in corticogenesis due to apparent mistiming of neurogenesis induction (Pierfelice et al., 2011; Tiberi et al., 2012; Bielen and Houart, 2014). For example, defective $\mathrm{Wnt}$ signaling caused by deletion of $\beta$-catenin transcriptional activity leads to a phenotype similar to that described in $L h \times 2-c K O$ cortices: premature neurogenesis, a small cortex, and fewer neurons in both deep and upper cortical layers (Draganova et al., 2015). Conversely, the hyperactivity of canonical Wnt signaling by overexpressing the stabilized form of $\beta$-catenin delays neurogenesis, causing overproliferation of APs through excessive symmetric divisions. This results in a cortex with increased surface area but decreased thickness (Chenn and Walsh, 2002, 2003). Interestingly, in the absence of Lhx2, the activation of $\beta$-catenin could no longer induce progenitor proliferation (Hsu et al., 2015). Further studies are needed to understand how these regulatory pathways are coordinated to control the timing of neurogenesis onset, and how their dysregulation produces cortical malformations.

Induction of neurogenesis involves the transition of APs from symmetric proliferative divisions to not only production of neurons directly through asymmetric divisions, but also indirectly through generation of IPs (Haubensak et al., 2004; Noctor et al.,
2004; Englund et al., 2005). As development proceeds, APs are more likely to produce an IP daughter than a neuronal daughter from their asymmetric divisions (Haubensak et al., 2004). IPs generally divide in the SVZ and have limited cell division potential (Noctor et al., 2004; Wu et al., 2005). They divide symmetrically to generate two postmitotic neurons or, more rarely, two IPs (Noctor et al., 2004; Sessa et al., 2008). Another type of neurogenic progenitor that may constitute a unique IP population was described in rodents as "short neural precursors" with short radial morphology within the VZ (Gal et al., 2006). These cells divide at the apical surface and express markers of neurogenic fate. Distinctions between APs and IPs can also be found in exhibition of different spindle microtubule behaviors during cytokinesis (Mora-Bermudez et al., 2014).

IPs have also emerged as key distinguishing factors in the development and evolution of cortical surface area and gyration in many mammalian species (Kriegstein et al., 2006; Borrell and Götz, 2014), as well as area-specific laminar patterns (Pontious et al., 2008). Despite our understanding of the lineage relationship between APs and IPs, the molecular mechanisms that control the transition of APs to generating IPs and their unique division behaviors remain elusive (Laguesse et al., 2015b). Interestingly, loss of inscutable in the mouse cortex impairs the generation of IPs, apparently by altering spindle orientation and therefore cleavage furrow angles of APs (Postiglione et al., 2011). This supports the notion that IP fate may be inhibited by inheritance of apical components. A key regulator of IPs is the transcription factor Tbr2 (Kowalczyk et al., 2009; Mihalas et al., 2016), which is expressed in IPs when they start to appear $\sim$ E11.5 in mice. Recently, Sox4 was identified as expressed in the cortical IP population, functioning as an upstream regulator of Tbr2 (C. Chen et al., 2015). Characterization of Sox4 mutants revealed its requirement in IP specification and maintenance in the cerebral cortex where it partners with the proneural gene Neurogenin 2 to activate Tbr2 for maintenance of an IP fate.

A novel regulatory mechanism for the generation of IPs has recently come to light. The Elongator complex, a histone acetyltransferase complex that associates directly with RNA polymerase II during transcriptional elongation, is required for proper generation of IPs in the developing cerebral cortex. Elongator is a macromolecular complex (Elp1-Elp6) expressed in the developing nervous system (Creppe et al., 2009) and mutations that decrease its function are associated with neurodegenerative diseases, such as ALS and familial dysautonomia (Anderson et al., 2001; Slaugenhaupt et al., 2001; Simpson et al., 2009) as well as intellectual disability and autism (Addis et al., 2015; Cohen et al., 2015). A role for this complex in the control of projection neuron migration and differentiation was through its acetylation of $\alpha$-tubulin (Creppe et al., 2009). Subsequently, a conditional knock-out model for Elp3 (Elp3-cKO) was generated to abolish its activity in APs (Laguesse et al., 2015a). Newborn Elp3-cKO mice suffer from severe microcephaly due to an increase in direct neurogenesis and concomitant decrease in indirect neurogenesis. Fewer IPs are generated, so even though APs divide at a normal rate, and divide asymmetrically, they make neuron daughters instead of IPs, resulting in a reduced number of projection neurons in all cortical layers. Additionally, a reduction in neurogenic potential of induced pluripotent stem cells derived from skin fibroblasts of patients suffering from familial dysautonomia was observed, correlating with reduced Elongator expression in these cells (Laguesse et al., 2015a). In mice, loss of Elp3 activity impaired translation speed, which triggered endoplasmic reticulum stress and the Unfolded Protein Response (UPR). More specifi- 
cally, a dynamic regulation of UPR is required for proper cortical neurogenesis, and a gradual suppression of the basal UPR promotes the switch in AP behavior from direct to indirect neurogenesis (Laguesse et al., 2015a). These findings revealed the existence of a signaling pathway downstream of the UPR to control cell fate acquisition of AP daughters and finely tune the balance of direct and indirect neurogenesis during mammalian cortical development (Godin et al., 2016). How exactly the level of UPR signaling causes an asymmetric division to result in a neuronal daughter versus an IP daughter, remains to be understood. Clues may come from findings that various UPR components regulate neuronal differentiation and process outgrowth (Favero et al., 2013; Godin et al., 2016). Continued efforts will be critical in better understanding molecular and cellular mechanisms that regulate the transition of APs to generate IPs at the correct time and in proper numbers to build a cortex of the proper size and structure.

\section{Capacity of single NSCs to generate the correct number and laminar fate of cortical neurons}

The progeny of cortical APs and IPs consist of a diverse population of excitatory projection neurons and glia that occupy the different cortical layers. These neurons are highly heterogeneous with diverse axonal projections, dendritic morphologies, and gene expression profiles. The laminar positions of cortical projection neurons are correlated with their birthdates, with deeplayer neurons (neurons in layers 5 and 6) generated earlier than upper-layer neurons (neurons in layers 2-4). For example, corticothalamic neurons, located in layer 6 , arise early from the cortical progenitors and project axons into the thalamus, whereas subcerebral projection neurons, residing in layer 5 , are born slightly later and project axons into midbrain, hindbrain, and spinal cord. Corticothalamic and subcerebral projection neurons are collectively referred to as corticofugal neurons. Corticocortical projection neurons, sending axons to other cortical areas, are distributed through all cortical layers; those in the upper cortical layer are generated last during cortical neurogenesis. The relationship between progenitors giving rise to deep-layer versus upper-layer neurons has long attracted research interest, and is still controversial.

Pioneering work using cell transplantation approaches in the developing ferret cortex suggested a progressive lineage restriction model of cortical progenitors (McConnell, 1985; McConnell and Kaznowski, 1991; Desai and McConnell, 2000). Accordingly, early APs are multipotent and can sequentially generate both deep- and upper-layer neurons, as well as cortical glia. As development proceeds, APs become progressively lineage-restricted to generate later-born cell types. Lineage analysis of individual APs in culture (Shen et al., 2006) and differentiation of cultured embryonic stem cell-derived cortical progenitors (Eiraku et al., 2008; Gaspard et al., 2008) have provided support for this model.

Further testing of the progressive lineage restriction model was done by genetic lineage tracing in vivo. The transcription factor Fezf2 is expressed in both APs and deep-layer projection neurons, and is necessary to specify the identity of these neurons (B. Chen et al., 2005; J.G. Chen et al., 2005; Molyneaux et al., 2005). In Fezf2 $2^{-1-}$ cortices, subcerebral projection neurons are never generated, and mutant neurons in layer 5 switch identity and become corticothalamic or callosal projection neurons (B. Chen et al., 2005, 2008; J.G. Chen et al., 2005; Molyneaux et al., 2005; McKenna et al., 2011). Conversely, ectopic expression of Fezf2 in late cortical progenitors or immature neurons redirects these cells to generate subcerebral neurons (B. Chen et al., 2005,
2008; J.G. Chen et al., 2005; De la Rossa et al., 2013; Rouaux and Arlotta, 2013). These results suggested that $\mathrm{Fezf2}^{+}$APs may constitute deep-layer restricted progenitors. To address this possibility, inducible mouse lines suitable for in vivo lineage tracing were used to compare $\mathrm{Fezf} 2^{+}$and progenitors expressing another transcription factor, Cux2. It turned out that both lineages appeared to be multipotent (i.e., they sequentially generate different subtypes of cortical projection neurons and glia) (Guo et al., 2013). To further determine whether the Fezf $2^{+}$and the $\mathrm{Cux} 2^{+} \mathrm{AP}$ populations contain any intrinsically lineage-restricted early progenitors, lineage analysis of individual APs was performed, and again both Fezf2 ${ }^{+}$APs and individual early $\mathrm{Cux2^{+ }}$ APs generated deepand upper-layer neurons, as well as glia (Eckler et al., 2015).

Despite the view that APs are gradually fate-restricted as corticogenesis proceeds, some experiments indicated that early (E10.5) $\mathrm{Cu}_{2} 2^{+}$APs produce restricted lineages. Using Cux2 ${ }^{\mathrm{Cre}}$ and $\mathrm{Cu} \times 2^{\mathrm{CreER}}$ alleles and Cre-dependent lineage analyses, Franco et al. reported that the $\mathrm{Cux}_{2}{ }^{+}$APs only produce upper-layer neurons (Franco et al., 2012; Gil-Sanz et al., 2015). This result suggested an intrinsic lineage restriction model (rather than progressive lineage restriction), which posits that upper-layer neurons are generated by early $\mathrm{Cux2^{+ }}$ APs, and deep-layer neurons are born from a different population of APs that mostly lack Cux2. Whether or not intrinsically restricted progenitors are also found in other AP populations remains to be determined.

An advantageous approach to test lineage-restricted or multipotent models of progenitor neurogenic potential is through high-resolution single-cell lineage tracing. Ideally, APs or IPs need to be genetically marked in a sparse but permanent manner to quantitatively measure progenitor behavior and progeny output. To this end, the Mosaic Analysis with Double Markers (MADMs) reporters provide an unprecedented genetic approach for in vivo lineage tracing in the mouse (Zong et al., 2005; Hippenmeyer et al., 2010; Hippenmeyer, 2013). Analysis of rare MADM-based mitotic recombination events, when controlled by the inducible cre-lox system, reveals the division mode of the first labeled progenitor division (symmetric or asymmetric) and its proliferation and differentiation potential (Espinosa and Luo, 2008; Hippenmeyer et al., 2010). An added MADM feature is the possible linkage of gene mutations on the same chromosome as the MADM cassette to enable genetic mosaic analysis. A single MADM clone will have two-color labeling such that the wild-type and homozygous mutant daughter cells of a heterozygous progenitor are marked by different colors. To gain insight into the precise final output patterns of neuronal and glial progeny generated by AP divisions in the cortex, MADM-based quantitative clonal analyses were recently performed (Gao et al., 2014). These findings suggest that the behaviors of APs in the cerebral cortices are remarkably coherent and predictable across all developmental stages. Importantly, MADM analyses of cortical clones revealed that APs labeled during the neurogenic phase do not undergo terminal differentiation in a stochastic manner but rather follow a defined nonrandom program of cell cycle exit, resulting in a unitary output of $\sim 8-9$ neurons per individual AP, distributed in both deep and superficial layers, supporting the progressive lineage model. Upon completion of neurogenesis, a defined fraction of individual cortical clones proceed to gliogenesis whereby approximately one-sixth of neurogenic APs proceed to produce macroglia, indicating a coupling between gliogenesis and neurogenesis at a predictable ratio (Gao et al., 2014). Future experiments will establish a precise quantitative framework of lineage progression in the cortex and degree of symmetric and 
asymmetric expansion of neurons and glia at various time points, which may be translated to other brain regions.

In conclusion, development of the cerebral cortex is highly dependent on temporal changes in the balance of types of divisions, and the ratios of proliferation versus differentiation and cell death. The ultimate outcome of the cellular and molecular events that regulate cell division and migration is the number and diversity of neurons and glia that occupy the layered mature cortex. Disruption of this process can lead to microcephaly, a disease recently put in the spotlight by the Zika virus outbreak. Beyond the regulation of their divisions, APs must also give rise to layerspecific neurons in proper sequence. Fate mapping studies and clonal lineage analyses support the idea that APs are gradually restricted in the fates they can produce, such that at later ages more upper-layer neurons are created. Together, the mechanisms highlighted here and in our SFN mini-symposium are potential entry points for future design of preventive and possibly corrective therapeutics that may help improve the life of patients suffering from neurodevelopmental conditions.

\section{References}

Abaza A, Soleilhac JM, Westendorf J, Piel M, Crevel I, Roux A, Pirollet F (2003) M phase phosphoprotein 1 is a human plus-end-directed kinesinrelated protein required for cytokinesis. J Biol Chem 278:27844-27852. CrossRef Medline

Addis L, Ahn JW, Dobson R, Dixit A, Ogilvie CM, Pinto D, Vaags AK, Coon H, Chaste P, Wilson S, Parr JR, Andrieux J, Lenne B, Tumer Z, Leuzzi V, Aubell K, Koillinen H, Curran S, Marshall CR, Scherer SW, et al. (2015) Microdeletions of ELP4 are associated with language impairment, autism spectrum disorder, and mental retardation. Hum Mutat 36:842-850. CrossRef Medline

Anderson SA, Eisenstat DD, Shi L, Rubenstein JL (1997) Interneuron migration from basal forebrain to neocortex: dependence on Dlx genes. Science 278:474-476. CrossRef Medline

Anderson SL, Coli R, Daly IW, Kichula EA, Rork MJ, Volpi SA, Ekstein J, Rubin BY (2001) Familial dysautonomia is caused by mutations of the IKAP gene. Am J Hum Genet 68:753-758. CrossRef Medline

Angevine JB Jr, Sidman RL (1961) Autoradiographic study of cell migration during histogenesis of cerebral cortex in the mouse. Nature 192:766-768. CrossRef Medline

Arai Y, Sampaio JL, Wilsch-Bräuninger M, Ettinger AW, Haffner C, Huttner WB (2015) Lipidome of midbody released from neural stem and progenitor cells during mammalian cortical neurogenesis. Front Cell Neurosci 9:325. CrossRef Medline

Asami M, Pilz GA, Ninkovic J, Godinho L, Schroeder T, Huttner WB, Götz M (2011) The role of Pax6 in regulating the orientation and mode of cell division of progenitors in the mouse cerebral cortex. Development 138: 5067-5078. CrossRef Medline

Atilla-Gokcumen GE, Muro E, Relat-Goberna J, Sasse S, Bedigian A, Coughlin ML, Garcia-Manyes S, Eggert US (2014) Dividing cells regulate their lipid composition and localization. Cell 156:428-439. CrossRef Medline

Bernabé-Rubio M, Andres G, Casares-Arias J, Fernández-Barrera J, Rangel L, Reglero-Real N, Gershlick DC, Fernández JJ, Millán J, Correas I, Miguez DG, Alonso MA (2016) Novel role for the midbody in primary ciliogenesis by polarized epithelial cells. J Cell Biol 214:259-273. CrossRef Medline

Bielen H, Houart C (2014) The Wnt cries many: Wnt regulation of neurogenesis through tissue patterning, proliferation, and asymmetric cell division. Dev Neurobiol 74:772-780. CrossRef Medline

Borrell V, Götz M (2014) Role of radial glial cells in cerebral cortex folding. Curr Opin Neurobiol 27:39-46. CrossRef Medline

Chai Y, Tian D, Yang Y, Feng G, Cheng Z, Li W, Ou G (2012) Apoptotic regulators promote cytokinetic midbody degradation in C. elegans. J Cell Biol 199:1047-1055. CrossRef Medline

Chen B, Schaevitz LR, McConnell SK (2005) Fezl regulates the differentiation and axon targeting of layer 5 subcortical projection neurons in cerebral cortex. Proc Natl Acad Sci U S A 102:17184-17189. CrossRef Medline

Chen B, Wang SS, Hattox AM, Rayburn H, Nelson SB, McConnell SK (2008)
The Fezf2-Ctip2 genetic pathway regulates the fate choice of subcortical projection neurons in the developing cerebral cortex. Proc Natl Acad Sci U S A 105:11382-11387. CrossRef Medline

Chen C, Lee GA, Pourmorady A, Sock E, Donoghue MJ (2015) Orchestration of neuronal differentiation and progenitor pool expansion in the developing cortex by SoxC genes. J Neurosci 35:10629-10642. CrossRef Medline

Chen JG, Rasin MR, Kwan KY, Sestan N (2005) Zfp312 is required for subcortical axonal projections and dendritic morphology of deep-layer pyramidal neurons of the cerebral cortex. Proc Natl Acad Sci U S A 102: 17792-17797. CrossRef Medline

Chenn A, McConnell SK (1995) Cleavage orientation and the asymmetric inheritance of Notchl immunoreactivity in mammalian neurogenesis. Cell 82:631-641. CrossRef Medline

Chenn A, Walsh CA (2002) Regulation of cerebral cortical size by control of cell cycle exit in neural precursors. Science 297:365-369. CrossRef Medline

Chenn A, Walsh CA (2003) Increased neuronal production, enlarged forebrains and cytoarchitectural distortions in beta-catenin overexpressing transgenic mice. Cereb Cortex 13:599-606. CrossRef Medline

Chou SJ, O'Leary DD (2013) Role for Lhx2 in corticogenesis through regulation of progenitor differentiation. Mol Cell Neurosci 56:1-9. CrossRef Medline

Chu J, Anderson SA (2015) Development of cortical interneurons. Neuropsychopharmacology 40:16-23. CrossRef Medline

Cohen JS, Srivastava S, Farwell KD, Lu HM, Zeng W, Lu H, Chao EC, Fatemi A (2015) ELP2 is a novel gene implicated in neurodevelopmental disabilities. Am J Med Genet A 167:1391-1395. CrossRef Medline

Creppe C, Malinouskaya L, Volvert ML, Gillard M, Close P, Malaise O, Laguesse S, Cornez I, Rahmouni S, Ormenese S, Belachew S, Malgrange B, Chapelle JP, Siebenlist U, Moonen G, Chariot A, Nguyen L (2009) Elongator controls the migration and differentiation of cortical neurons through acetylation of alpha-tubulin. Cell 136:551-564. CrossRef Medline

Crowell EF, Gaffuri AL, Gayraud-Morel B, Tajbakhsh S, Echard A (2014) Engulfment of the midbody remnant after cytokinesis in mammalian cells. J Cell Sci 127:3840-3851. CrossRef Medline

De la Rossa A, Bellone C, Golding B, Vitali I, Moss J, Toni N, Lüscher C, Jabaudon D (2013) In vivo reprogramming of circuit connectivity in postmitotic neocortical neurons. Nat Neurosci 16:193-200. CrossRef Medline

Dehay C, Kennedy H, Kosik KS (2015) The outer subventricular zone and primate-specific cortical complexification. Neuron 85:683-694. CrossRef Medline

Desai AR, McConnell SK (2000) Progressive restriction in fate potential by neural progenitors during cerebral cortical development. Development 127:2863-2872. Medline

Draganova K, Zemke M, Zurkirchen L, Valenta T, Cantù C, Okoniewski M, Schmid MT, Hoffmans R, Götz M, Basler K, Sommer L (2015) Wnt/ $\beta$ catenin signaling regulates sequential fate decisions of murine cortical precursor cells. Stem Cells 33:170-182. CrossRef Medline

Dubreuil V, Marzesco AM, Corbeil D, Huttner WB, Wilsch-Bräuninger M (2007) Midbody and primary cilium of neural progenitors release extracellular membrane particles enriched in the stem cell marker prominin-1. J Cell Biol 176:483-495. CrossRef Medline

Dwyer ND, Manning DK, Moran JL, Mudbhary R, Fleming MS, Favero CB, Vock VM, O'Leary DD, Walsh CA, Beier DR (2011) A forward genetic screen with a thalamocortical axon reporter mouse yields novel neurodevelopment mutants and a distinct emx2 mutant phenotype. Neural Dev 6:3. CrossRef Medline

Eckler MJ, Nguyen TD, McKenna WL, Fastow BL, Guo C, Rubenstein JL, Chen B (2015) Cux2-positive radial glial cells generate diverse subtypes of neocortical projection neurons and macroglia. Neuron 86:1100-1108. CrossRef Medline

Eiraku M, Watanabe K, Matsuo-Takasaki M, Kawada M, Yonemura S, Matsumura M, Wataya T, Nishiyama A, Muguruma K, Sasai Y (2008) Selforganized formation of polarized cortical tissues from ESCs and its active manipulation by extrinsic signals. Cell Stem Cell 3:519-532. CrossRef Medline

Elia N, Sougrat R, Spurlin TA, Hurley JH, Lippincott-Schwartz J (2011) Dynamics of endosomal sorting complex required for transport (ESCRT) machinery during cytokinesis and its role in abscission. Proc Natl Acad Sci U S A 108:4846-4851. CrossRef Medline 
Englund C, Fink A, Lau C, Pham D, Daza RA, Bulfone A, Kowalczyk T, Hevner RF (2005) Pax6, Tbr2, and Tbr1 are expressed sequentially by radial glia, intermediate progenitor cells, and postmitotic neurons in developing neocortex. J Neurosci 25:247-251. CrossRef Medline

Espinosa JS, Luo L (2008) Timing neurogenesis and differentiation: insights from quantitative clonal analyses of cerebellar granule cells. J Neurosci 28:2301-2312. CrossRef Medline

Ettinger AW, Wilsch-Bräuninger M, Marzesco AM, Bickle M, Lohmann A, Maliga Z, Karbanová J, Corbeil D, Hyman AA, Huttner WB (2011) Proliferating versus differentiating stem and cancer cells exhibit distinct midbody-release behaviour. Nat Commun 2:503. CrossRef Medline

Faheem M, Naseer MI, Rasool M, Chaudhary AG, Kumosani TA, Ilyas AM, Pushparaj P, Ahmed F, Algahtani HA, Al-Qahtani MH, Saleh JH (2015) Molecular genetics of human primary microcephaly: an overview. BMC Med Genomics 8 [Suppl 1]:S4.

Favero CB, Henshaw RN, Grimsley-Myers CM, Shrestha A, Beier DR, Dwyer ND (2013) Mutation of the BiP/GRP78 gene causes axon outgrowth and fasciculation defects in the thalamocortical connections of the mammalian forebrain. J Comp Neurol 521:677-696. CrossRef Medline

Fernández V, Llinares-Benadero C, Borrell V (2016) Cerebral cortex expansion and folding: what have we learned? EMBO J 35:1021-1044. CrossRef Medline

Florio M, Huttner WB (2014) Neural progenitors, neurogenesis and the evolution of the neocortex. Development 141:2182-2194. CrossRef Medline

Franco SJ, Gil-Sanz C, Martinez-Garay I, Espinosa A, Harkins-Perry SR, Ramos C, Müller U (2012) Fate-restricted neural progenitors in the mammalian cerebral cortex. Science 337:746-749. CrossRef Medline

Gal JS, Morozov YM, Ayoub AE, Chatterjee M, Rakic P, Haydar TF (2006) Molecular and morphological heterogeneity of neural precursors in the mouse neocortical proliferative zones. J Neurosci 26:10451056. CrossRef Medline

Gallo V, Deneen B (2014) Glial development: the crossroads of regeneration and repair in the CNS. Neuron 83:283-308. CrossRef Medline

Gao P, Postiglione MP, Krieger TG, Hernandez L, Wang C, Han Z, Streicher C, Papusheva E, Insolera R, Chugh K, Kodish O, Huang K, Simons BD, Luo L, Hippenmeyer S, Shi SH (2014) Deterministic progenitor behavior and unitary production of neurons in the neocortex. Cell 159:775788. CrossRef Medline

Gaspard N, Bouschet T, Hourez R, Dimidschstein J, Naeije G, van den Ameele J, Espuny-Camacho I, Herpoel A, Passante L, Schiffmann SN, Gaillard A, Vanderhaeghen P (2008) An intrinsic mechanism of corticogenesis from embryonic stem cells. Nature 455:351-357. CrossRef Medline

Gil-Sanz C, Espinosa A, Fregoso SP, Bluske KK, Cunningham CL, MartinezGaray I, Zeng H, Franco SJ, Müller U (2015) Lineage tracing using Cux2-Cre and Cux2-CreERT2 mice. Neuron 86:1091-1099. CrossRef Medline

Godin JD, Creppe C, Laguesse S, Nguyen L (2016) Emerging roles for the unfolded protein response in the developing nervous system. Trends Neurosci 39:394-404. CrossRef Medline

Green RA, Paluch E, Oegema K (2012) Cytokinesis in animal cells. Annu Rev Cell Dev Biol 28:29-58. CrossRef Medline

Guo C, Eckler MJ, McKenna WL, McKinsey GL, Rubenstein JL, Chen B (2013) Fezf2 expression identifies a multipotent progenitor for neocortical projection neurons, astrocytes, and oligodendrocytes. Neuron 80: 1167-1174. CrossRef Medline

Harding BN, Moccia A, Drunat S, Soukarieh O, Tubeuf H, Chitty LS, Verloes A, Gressens P, El Ghouzzi V, Joriot S, Di Cunto F, Martins A, Passemard S, Bielas SL (2016) Mutations in citron kinase cause recessive microlissencephaly with multinucleated neurons. Am J Hum Genet 99:511-520. CrossRef Medline

Haubensak W, Attardo A, Denk W, Huttner WB (2004) Neurons arise in the basal neuroepithelium of the early mammalian telencephalon: a major site of neurogenesis. Proc Natl Acad Sci U S A 101:3196-3201. CrossRef Medline

Heng JI, Chariot A, Nguyen L (2010) Molecular layers underlying cytoskeletal remodelling during cortical development. Trends Neurosci 33:3847. CrossRef Medline

Hippenmeyer S (2013) Dissection of gene function at clonal level using mosaic analysis with double markers. Front Biol 8:557-568.

Hippenmeyer S, Youn YH, Moon HM, Miyamichi K, Zong H, Wynshaw-
Boris A, Luo L (2010) Genetic mosaic dissection of Lis1 and Ndel1 in neuronal migration. Neuron 68:695-709. CrossRef Medline

Homem CC, Repic M, Knoblich JA (2015) Proliferation control in neural stem and progenitor cells. Nat Rev Neurosci 16:647-659. CrossRef Medline

Hsu LC, Nam S, Cui Y, Chang CP, Wang CF, Kuo HC, Touboul JD, Chou SJ (2015) Lhx2 regulates the timing of beta-catenin-dependent cortical neurogenesis. Proc Natl Acad Sci U S A 112:12199-12204. CrossRef Medline

Hu CK, Coughlin M, Mitchison TJ (2012) Midbody assembly and its regulation during cytokinesis. Mol Biol Cell 23:1024-1034. CrossRef Medline

Janisch KM, Dwyer ND (2016) Imaging and quantitative analysis of cytokinesis in developing brains of Kinesin- 6 mutant mice. Methods Cell Biol 131:233-252. CrossRef Medline

Janisch KM, Vock VM, Fleming MS, Shrestha A, Grimsley-Myers CM, Rasoul BA, Neale SA, Cupp TD, Kinchen JM, Liem KF Jr, Dwyer ND (2013) The vertebrate-specific Kinesin-6, Kif20b, is required for normal cytokinesis of polarized cortical stem cells and cerebral cortex size. Development 140:4672-4682. CrossRef Medline

Jongsma ML, Berlin I, Neefjes J (2015) On the move: organelle dynamics during mitosis. Trends Cell Biol 25:112-124. CrossRef Medline

Knoblach B, Rachubinski RA (2015) Motors, anchors, and connectors: orchestrators of organelle inheritance. Annu Rev Cell Dev Biol 31:55-81. CrossRef Medline

Konno D, Shioi G, Shitamukai A, Mori A, Kiyonari H, Miyata T, Matsuzaki F (2008) Neuroepithelial progenitors undergo LGN-dependent planar divisions to maintain self-renewability during mammalian neurogenesis. Nat Cell Biol 10:93-101. CrossRef Medline

Kosodo Y, Röper K, Haubensak W, Marzesco AM, Corbeil D, Huttner WB (2004) Asymmetric distribution of the apical plasma membrane during neurogenic divisions of mammalian neuroepithelial cells. EMBO J 23: 2314-2324. CrossRef Medline

Kosodo Y, Toida K, Dubreuil V, Alexandre P, Schenk J, Kiyokage E, Attardo A, Mora-Bermúdez F, Arii T, Clarke JD, Huttner WB (2008) Cytokinesis of neuroepithelial cells can divide their basal process before anaphase. EMBO J 27:3151-3163. CrossRef Medline

Kowalczyk T, Pontious A, Englund C, Daza RA, Bedogni F, Hodge R, Attardo A, Bell C, Huttner WB, Hevner RF (2009) Intermediate neuronal progenitors (basal progenitors) produce pyramidal-projection neurons for all layers of cerebral cortex. Cereb Cortex 19:2439-2450. CrossRef Medline

Kriegstein A, Noctor S, Martínez-Cerdeno V (2006) Patterns of neural stem and progenitor cell division may underlie evolutionary cortical expansion. Nat Rev Neurosci 7:883-890. CrossRef Medline

Kuo TC, Chen CT, Baron D, Onder TT, Loewer S, Almeida S, Weismann CM, Xu P, Houghton JM, Gao FB, Daley GQ, Doxsey S (2011) Midbody accumulation through evasion of autophagy contributes to cellular reprogramming and tumorigenicity. Nat Cell Biol 13:1214-1223. CrossRef Medline

Laguesse S, Creppe C, Nedialkova DD, Prévot PP, Borgs L, Huysseune S, Franco B, Duysens G, Krusy N, Lee G, Thelen N, Thiry M, Close P, Chariot A, Malgrange B, Leidel SA, Godin JD, Nguyen L (2015a) A dynamic unfolded protein response contributes to the control of cortical neurogenesis. Dev Cell 35:553-567. CrossRef Medline

Laguesse S, Peyre E, Nguyen L (2015b) Progenitor genealogy in the developing cerebral cortex. Cell Tissue Res 359:17-32. CrossRef Medline

LaMonica BE, Lui JH, Hansen DV, Kriegstein AR (2013) Mitotic spindle orientation predicts outer radial glial cell generation in human neocortex. Nat Commun 4:1665. CrossRef Medline

Lenhart KF, DiNardo S (2015) Somatic cell encystment promotes abscission in germline stem cells following a regulated block in cytokinesis. Dev Cell 34:192-205. CrossRef Medline

Li H, Bielas SL, Zaki MS, Ismail S, Farfara D, Um K, Rosti RO, Scott EC, Tu S, Chi NC, Gabriel S, Erson-Omay EZ, Ercan-Sencicek AG, Yasuno K, Çağlayan AO, Kaymakçalan H, Ekici B, Bilguvar K, Gunel M, Gleeson JG (2016) Biallelic mutations in citron kinase link mitotic cytokinesis to human primary microcephaly. Am J Hum Genet 99:501-510. CrossRef Medline

Liang H, Xiao G, Yin H, Hippenmeyer S, Horowitz JM, Ghashghaei HT (2013) Neural development is dependent on the function of specificity protein 2 in cell cycle progression. Development 140:552-561. CrossRef Medline 
Marthiens V, ffrench-Constant C (2009) Adherens junction domains are split by asymmetric division of embryonic neural stem cells. EMBO Rep 10:515-520. CrossRef Medline

McConnell SK (1985) Migration and differentiation of cerebral cortical neurons after transplantation into the brains of ferrets. Science 229:12681271. CrossRef Medline

McConnell SK, Kaznowski CE (1991) Cell cycle dependence of laminar determination in developing neocortex. Science 254:282-285. CrossRef Medline

McKenna WL, Betancourt J, Larkin KA, Abrams B, Guo C, Rubenstein JL, Chen B (2011) Tbr1 and Fezf2 regulate alternate corticofugal neuronal identities during neocortical development. J Neurosci 31:549-564. CrossRef Medline

Mierzwa B, Gerlich DW (2014) Cytokinetic abscission: molecular mechanisms and temporal control. Dev Cell 31:525-538. CrossRef Medline

Mihalas AB, Elsen GE, Bedogni F, Daza RA, Ramos-Laguna KA, Arnold SJ, Hevner RF (2016) Intermediate progenitor cohorts differentially generate cortical layers and require Tbr2 for timely acquisition of neuronal subtype identity. Cell Rep 16:92-105. CrossRef Medline

Miyata T, Kawaguchi A, Okano H, Ogawa M (2001) Asymmetric inheritance of radial glial fibers by cortical neurons. Neuron 31:727-741. CrossRef Medline

Molyneaux BJ, Arlotta P, Hirata T, Hibi M, Macklis JD (2005) Fezl is required for the birth and specification of corticospinal motor neurons. Neuron 47:817-831. CrossRef Medline

Mora-Bermudez F, Matsuzaki F, Huttner WB (2014) Specific polar subpopulations of astral microtubules control spindle orientation and symmetric neural stem cell division. Elife 4:3. CrossRef Medline

Noctor SC, Martínez-Cerdeño V, Ivic L, Kriegstein AR (2004) Cortical neurons arise in symmetric and asymmetric division zones and migrate through specific phases. Nat Neurosci 7:136-144. CrossRef Medline

Noctor SC, Martínez-Cerdeño V, Kriegstein AR (2008) Distinct behaviors of neural stem and progenitor cells underlie cortical neurogenesis. J Comp Neurol 508:28-44. CrossRef Medline

Paolini A, Duchemin AL, Albadri S, Patzel E, Bornhorst D, González Avalos P, Lemke S, Machate A, Brand M, Sel S, Di Donato V, Del Bene F, Zolessi FR, Ramialison M, Poggi L (2015) Asymmetric inheritance of the apical domain and self-renewal of retinal ganglion cell progenitors depend on Anillin function. Development 142:832-839. CrossRef Medline

Pierfelice T, Alberi L, Gaiano N (2011) Notch in the vertebrate nervous system: an old dog with new tricks. Neuron 69:840-855. CrossRef Medline

Paridaen JT, Wilsch-Bräuninger M, Huttner WB (2013) Asymmetric inheritance of centrosome-associated primary cilium membrane directs ciliogenesis after cell division. Cell 155:333-344. CrossRef Medline

Pollarolo G, Schulz JG, Munck S, Dotti CG (2011) Cytokinesis remnants define first neuronal asymmetry in vivo. Nat Neurosci 14:1525-1533. CrossRef Medline

Pontious A, Kowalczyk T, Englund C, Hevner RF (2008) Role of intermediate progenitor cells in cerebral cortex development. Dev Neurosci 30:2432. CrossRef Medline

Postiglione MP, Jüschke C, Xie Y, Haas GA, Charalambous C, Knoblich JA (2011) Mouse inscuteable induces apical-basal spindle orientation to facilitate intermediate progenitor generation in the developing neocortex. Neuron 72:269-284. CrossRef Medline

Rakic P (1972) Mode of cell migration to the superficial layers of fetal monkey neocortex. J Comp Neurol 145:61-83. CrossRef Medline

Rhyu MS, Jan LY, Jan YN (1994) Asymmetric distribution of numb protein during division of the sensory organ precursor cell confers distinct fates to daughter cells. Cell 76:477-491. CrossRef Medline
Rouaux C, Arlotta P (2013) Direct lineage reprogramming of post-mitotic callosal neurons into corticofugal neurons in vivo. Nat Cell Biol 15:214221. CrossRef Medline

Salzmann V, Chen C, Chiang CY, Tiyaboonchai A, Mayer M, Yamashita YM (2014) Centrosome-dependent asymmetric inheritance of the midbody ring in Drosophila germline stem cell division. Mol Biol Cell 25:267-275. CrossRef Medline

Sapir T, Levy T, Sakakibara A, Rabinkov A, Miyata T, Reiner O (2013) Shootin1 acts in concert with KIF20B to promote polarization of migrating neurons. J Neurosci 33:11932-11948. CrossRef Medline

Sessa A, Mao CA, Hadjantonakis AK, Klein WH, Broccoli V (2008) Tbr2 directs conversion of radial glia into basal precursors and guides neuronal amplification by indirect neurogenesis in the developing neocortex. Neuron 60:56-69. CrossRef Medline

Shen Q, Wang Y, Dimos JT, Fasano CA, Phoenix TN, Lemischka IR, Ivanova NB, Stifani S, Morrisey EE, Temple S (2006) The timing of cortical neurogenesis is encoded within lineages of individual progenitor cells. Nat Neurosci 9:743-751. CrossRef Medline

Simpson CL, Lemmens R, Miskiewicz K, Broom WJ, Hansen VK, van Vught PW, Landers JE, Sapp P, Van Den Bosch L, Knight J, Neale BM, Turner MR, Veldink JH, Ophoff RA, Tripathi VB, Beleza A, Shah MN, Proitsi P, Van Hoecke A, Carmeliet P, et al. (2009) Variants of the elongator protein 3 (ELP3) gene are associated with motor neuron degeneration. Hum Mol Genet 18:472-481. CrossRef Medline

Singh D, Pohl C (2014) Coupling of rotational cortical flow, asymmetric midbody positioning, and spindle rotation mediates dorsoventral axis formation in C. elegans. Dev Cell 28:253-267. CrossRef Medline

Skop AR, Liu H, Yates J 3rd, Meyer BJ, Heald R (2004) Dissection of the mammalian midbody proteome reveals conserved cytokinesis mechanisms. Science 305:61-66. CrossRef Medline

Slaugenhaupt SA, Blumenfeld A, Gill SP, Leyne M, Mull J, Cuajungco MP, Liebert CB, Chadwick B, Idelson M, Reznik L, Robbins C, Makalowska I, Brownstein M, Krappmann D, Scheidereit C, Maayan C, Axelrod FB, Gusella JF (2001) Tissue-specific expression of a splicing mutation in the IKBKAP gene causes familial dysautonomia. Am J Hum Genet 68 : 598-605. CrossRef Medline

Suter B, Nowakowski RS, Bhide PG, Caviness VS (2007) Navigating neocortical neurogenesis and neuronal specification: a positional information system encoded by neurogenetic gradients. J Neurosci 27:10777-10784. CrossRef Medline

Tiberi L, Vanderhaeghen P, van den Ameele J (2012) Cortical neurogenesis and morphogens: diversity of cues, sources and functions. Curr Opin Cell Biol 24:269-276. CrossRef Medline

Tsunekawa Y, Britto JM, Takahashi M, Polleux F, Tan SS, Osumi N (2012) Cyclin D2 in the basal process of neural progenitors is linked to nonequivalent cell fates. EMBO J 31:1879-1892. CrossRef Medline

Tyler WA, Medalla M, Guillamon-Vivancos T, Luebke JI, Haydar TF (2015) Neural precursor lineages specify distinct neocortical pyramidal neuron types. J Neurosci 35:6142-6152. CrossRef Medline

Wang X, Tsai JW, Imai JH, Lian WN, Vallee RB, Shi SH (2009) Asymmetric centrosome inheritance maintains neural progenitors in the neocortex. Nature 461:947-955. CrossRef Medline

Wu SX, Goebbels S, Nakamura K, Nakamura K, Kometani K, Minato N, Kaneko T, Nave KA, Tamamaki N (2005) Pyramidal neurons of upper cortical layers generated by NEX-positive progenitor cells in the subventricular zone. Proc Natl Acad Sci U S A 102:17172-17177. CrossRef Medline

Zong H, Espinosa JS, Su HH, Muzumdar MD, Luo L (2005) Mosaic analysis with double markers in mice. Cell 121:479-492. CrossRef Medline 